International Journal of Education and Practice

2021 Vol. 9, No. 2, pp. 379-395.

$\operatorname{ISSN}(e): 2310-3868$

$\operatorname{ISSN}(p): 2311-6897$

DOI: $10.18488 /$ journal.61.2021.92.379.395

(C) 2021 Conscientia Beam. All Rights Reserved.

check for
updates

\title{
ONLINE LEARNING CHALLENGES AFFECTING STUDENTS OF ENGLISH IN AN EFL CONTEXT DURING COVID-19 PANDEMIC
}

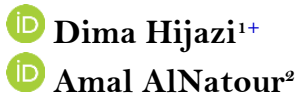

Amal AlNatour ${ }^{2}$

\author{
${ }^{1,2}$ Yarmouk University, Language Centre, Irbid, Jordan. \\ ${ }^{2}$ Email:dimahijazi22@yahoo.com Tel: +962791594003 \\ 'Email:Amalnatour13@yahoo.com Tel: +962795701391
}

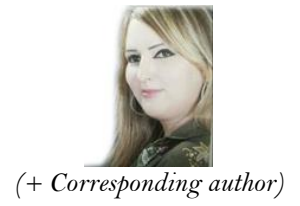

ABSTRACT

\section{Article History}

Received: 13 January 202 Revised: 11 March 2021 Accepted: 9 April 2021 Published: 23 April 2021

\section{Keywords}

Challenges

Coordination

COVID-19 pandemic

Distance education and online

learning

EFL context

Infrastructure

Students of English.
The sudden and rapid changes in the world due to the COVID-19 pandemic have led to a shift in the educational methods used in educational facilities. Challenges faced by both students and lecturers have led to a quality difference in the education provided. This study was carried out on students who joined EFL English-99 and English-101 courses that enforced online learning during the 2019/2020 summer semester at Yarmouk University. A quantitative approach was used to answer the question of this study: What are the online learning challenges faced by English language students in an EFL context during COVID-19 Pandemic? A questionnaire of 52 items was sent online to 1,200 students to find the causes of the quality change. The items aimed to determine the effect on the student experience of the following challenges: infrastructure, computer skills, coordination, teaching methods, motivation \& willingness, assessment methods and social aspects. The results showed the severity of the challenges as following: teaching methods, social aspects, infrastructure, computer skills and coordination all showed a high degree of challenge, and assessment methods, motivation \& willingness came with a moderate degree of challenge. The researchers recommend conducting further research to determine solutions for the challenges faced by students in an EFL context in the online learning environment.

Contribution/Originality: This study is one of few studies which have investigated the challenges affecting students when using completely online education in emergency situations. It will contribute to encourage academicians and authorities to find solutions to eliminate such challenges while maintaining a high-quality education via adopting productive online education practices.

\section{BACKGROUND}

Ever since the beginning of 2020, the world has been under a lot of pressure to preserve mankind from the rapid mutant viral disease COVID-19. In mid-March, as a result of the unprecedented health and socio-economic crisis caused by this virus, most governments rapidly applied defense laws to restrict the movement of humans in order to reduce the spread of the virus. All sectors were subjected to certain restrictions and a halt of practicing many of their different activities as usual, and educational institutes were no exception: students, teachers and instructors were obliged to stay at home.

In the Jordanian context, the government took extreme actions to stop the spread of the virus, which was dramatically multiplying in the surrounding countries and in the world. Such actions resulted in the suspension of schools, the banning of public gatherings, and the closing of borders and airports. The rapid shift in events needed a 
quick response to ensure the sustainability of the educational process. Educational institutes worldwide had to shift from conventional and hybrid methods to online education.

This helped reduce the spread of the virus, but at the same time, the quality of education was affected. In this paper, the researchers discuss the challenges of online learning that affect the nature of education, especially for university students who learn English as a foreign language.

\section{INTRODUCTION}

Education is the backbone of modern society; it shapes the nations into what they are, and limits what they can achieve, especially in countries with low resources. The main resource these countries have is their people, and those people and their education levels are key determinants in the growth of their country. Since 30 January 2020, the outbreak of COVID-19 has been considered an international concern (World Health Organization, 2020). The pandemic has generated the greatest disruption of education systems in history. United Nations (2020) states that COVID-19 has affected nearly 1.6 billion learners in more than 190 countries. Like many other aspects of everyday life, this has led to a significant impact on the elements of education worldwide (Mailizar, Maulina, \& Bruce, 2020).

To adapt to events, the world shifted to online education, to guarantee that students were not left without education in the pandemic era. This innovative shift required improved technology and required instructors to adjust their working environments. Notably, with this unanticipated shift away from the classroom, many have doubted about the successful adoption of online learning and are concerned about how such a shift will affect the worldwide education market.

Online education is defined as a kind of distance education since all the instructions and assessments are executed using the internet (Picciano \& Seaman, 2009). Before applying such an approach, a key factor should be taken into consideration, which is how ready students are to be engaged in an online context (Watkins, Leigh, \& Triner, 2004). In general, a student's capacity to be successful in traditional education is not sufficient to ensure success in an online learning environment. Liguori and Winkler (2020) state that the success of digital teaching varies depending on the broad-spectrum learning goals that direct our pedagogical and educational prime concerns.

Online learning has great value that we cannot ignore, and many of our fellow researchers have written about the benefits (e.g., (Al-Diab, Hijazi, \& AlNatour, 2018; Evans \& Fan, 2002; Mandernach, Mason, Forrest, \& Hackathorn, 2012; Naidu, 2019; O’Donoghue, O’Neill, \& Singh, 2004; Sadeghi, 2019; Santana, Torres Penedo, \& Pereira, 2018)). However, there are certain challenges connected with online learning which have been discussed in various studies, such as the lack of technical competence either of educators or students, or the lack of relationships and social interactions between students which may make them feel isolated or frustrated (Anwar \& Adnan, 2020). There are other challenges, like the lack of control of the lecturer over the learning environment and the urgent need for procedures to discipline and organize the students. Other problems include the lack of students' interest in the subject they study and the difficulties in obtaining instructional techniques used for enhancing students' abilities to become independent problem-solvers (Doghonadze, Halawachy, Samuel, Adedoyin, \& Aliyew, 2020).

In a country where most universities use conventional teaching methods and a handful of universities use hybrid learning methods, translating education to become fully online was a challenge for educators as well as students. The researchers believe that the quality of education is not so effective as it was before the pandemic. Thus, this paper investigated the obstacles to online learning faced by English language students in an EFL context during the COVID-19 Pandemic.

\subsection{Problem Statement}

The problem in this study may have resulted from the sudden and dramatic shift into online learning. There were no guidebooks telling the educators how to run online classes, and neither the infrastructure nor students were ready for the move online. The uncertainty of how rapidly the virus would spread, and how long it would be a 
threat, made the task of online education a challenge. As instructors of English at Yarmouk University, the researchers noticed that the students' willingness to learn a new language during the online semester, with all the technical challenges and difficulties they faced, did not enable them to acquire the knowledge intended from the courses. To make the picture clearer and to respond to the university's regulations to follow up the problems of maintaining the quality of education, the researchers conducted this study to discover the barriers that students may face while learning via the online approach.

\subsection{Purpose of the Study}

The purpose of this study is to determine the online learning challenges that were affecting students studying English-101 and English-99 in an EFL context during the Covid-19 Pandemic.

\subsection{Research Question}

In this study, the researchers attempt to answer the following research question: What are the online learning challenges faced by English language students in an EFL context during the COVID-19 Pandemic?

\subsection{Significance of the Study}

The importance of this study stems from the fact that the world is going through a global pandemic that requires a change in teaching methods, along with the reality that online education in EFL contexts is going through a lot of challenges that affect the quality of education and the quality of learning. The results of this study are vital for developing education quality assurance in many countries since they face the same challenges. Initially, this study assisted in revealing crucial issues of student engagement in their education during and after the COVID-19 pandemic. Such issues could be used as a reference for other scholars to conduct further research in other educational contexts or could be used by concerned authorities to upgrade their educational initiatives.

Notably, the results will be of great benefit to the instructors since they are in direct communication with the students and will be able to understand their experiences better and to discuss with them problems relating to online management. Finally, the results of the study can be used to improve post-pandemic educational systems and education quality and to reduce the costs on the educational facilities as they will be able to adopt productive online education practices.

\subsection{Operational Definitions of Terms}

- Online learning: A learning process in which the education is totally delivered using the internet.

- EFL Context: A context where English is taught as a foreign language.

- ICT: Information and Communications Technology.

- English language students: Male and female students studying English 101 and 99 at Yarmouk University during the summer semester of the academic year 2019/2020.

-Infrastructure: The required software and hardware materials, and personnel involved in achieving a productive learning.

-Coordination: The organization level between students and lecturers, lecturers and other lecturers, and lecturers and the organization in which they work.

-Domains: The challenges discussed in the questionnaire.

-Items: The sub-issues constituting the domain challenges.

\subsection{Limitations of the Study}

The generalization of the results of this study is limited to all male and female Yarmouk University students studying English 101 and English 99 enrolled in the summer semester of the academic year 2019/2020. 


\section{LITERATURE REVIEW}

Many studies have discussed the problems associated with the implementation of online learning. Most of them show that institutions and their members were not prepared for the experience, especially in developing countries. The advent of online teaching initiatives is full of challenges and struggles (Aydin \& Tasci, 2005; Borotis \& Poulymenakou, 2004). Despite the fact that a lot of studies have addressed the significance and limitations of the online learning approach, little research has been performed on the challenges involved in the transition from the conventional method of teaching without a blended approach to completely online education in emergency situations. In this review, the researchers will investigate the findings of previous work on the challenges of online education before the pandemic and at the time of this work to see if the same challenges still exist, and their relationship to the challenges found in the current study.

We will begin with studies emphasizing the challenges of online education before the COVID-19 outbreak. Muilenburg and Berge (2005) carried out a study on 1,056 participants using both a pilot and a main study. The pilot study on 423 participants consisted of a survey with 61 items. After the survey, statistical analysis was performed. The factors resulting from the pilot study were grouped and used in the main study with 1,056 participants, which investigated the effect of 47 barriers to online learning. Factor scores were calculated for each of eight assigned factors. The means for the eight factors were used to rank the barriers from the most severe to the least as follows: administrative issues, social issues, academic issues, technical issues, motivational issues, time and support, cost, and access to the internet.

Peytcheva-Forsyth, Yovkova, and Aleksieva (2018) performed a study in which the level of student acceptance of the introduction of online learning was identified in a sample of 590 students. By collecting data via a questionnaire, they were able to find that the students' previous experiences in using technology and web applications in an educational context played a huge role in the acceptance of online learning, as well as the student's level of computer literacy. This is similar to another study, where students were also affected by the excellence and ease of using the courses during online learning (Aixia \& Wang, 2011). The students' level of computer literacy and previously attained computer skills had a high impact on their performance.

In 2019, a study was conducted to find out the challenges faced by Iranian students due to e-learning at the virtual school of medical studies in Shiraz University (Shafiei Sarvestani, Mohammadi, Afshin, \& Raeisy, 2019). Qualitative methods and phenomenological analyses were used to determine the challenges faced by 10 selected students. The findings classified the challenges into six categories: educational, ethical, technical, evaluative, managerial and communicational challenges. Each category had the common issues addressed in most of the studies on online education such as: negative perceptions of e-learning, low internet speeds, lack of interaction with the instructors and inefficiency of the educational content (Shafiei Sarvestani et al., 2019).

Aboagye, Yawson, and Appiah (2020) explored the challenges that students face in online learning in tertiary institutions in Ghana in the era of the Coronavirus pandemic. The study was performed on 141 students. The research instrument was a questionnaire which consisted of 30 items. The results revealed that the challenges could be classified into eight groups: social issues, lecturer issues, accessibility issues, learner motivation, academic issues, generic issues, learner intentions, and demographics. Also, they revealed that the most important challenge for students in studying online was issues with accessibility, followed by social, lecturer, academic, and generic issues.

Aboagye and Yawson (2020) examined the challenges faced by tutors at colleges of education in Ghana as a result of the transition from the traditional method to a completely online method in the COVID-19 era. Questionnaires and semi-structured interviews were used to gather the needed data. The results revealed that factors such as infrastructure, teaching methods, learning management systems and students made it difficult for educators to successfully deliver online learning. However, it was revealed that the costs of using online methods in the teaching and learning process are high; therefore, it requires assistance from stakeholders to achieve successful implementation. 
Ali (2020) conducted a study to find out some of the challenges and benefits of integrating online learning in tertiary institutions in response to the COVID-19 pandemic. The methodology for the researcher's study was a meta-analysis where he gathered data from multiple scientific studies addressing the same questions. His findings revealed that the set of challenges highlighted by the World Bank (2020) must be taken into consideration. Those challenges are listed as the following: Students' under-performance, missing out on social aspects, low engagement, high dropout, low completion, low retention rates, no or little supervision, internet connectivity, electricity and access to digital devices. He also added that infrastructure, and staff readiness and confidence are needed in ICT integrated learning.

Baticulon et al. (2020) determined the challenges faced by medical students using online training in developing countries. To collect the data, an electronic survey with multiple analysis methods was sent to medical students in the Philippines. The results of the survey showed that more students were unwilling to engage in online education during the pandemic than previously and that only $41 \%$ of the students were ready to engage in online learning. The unwillingness and unreadiness might be due to the barriers classified by the researchers, including technological, individual, institutional and community barriers.

Girik Allo (2020) investigated learners' perceptions of online learning during the COVID-19 pandemic. The study sampled students of the English program of UKI Toraja. The instrument used was a semi-structured interview. The researchers interviewed the learners by calling them using the WhatsApp application. In this case, the students found that using online learning during the COVID-19 pandemic was good and helpful. Students hoped that the lecturers would make use of trending applications such as free Messenger applications in the online learning system. Additionally, they said that individual tasks helped keep the physical distance required due to the pandemic and that they needed group tasks to help friends who did not have internet access. Also, they hoped that materials and assignments would be preceded by an explanation. For this purpose, they recommended that VoiceNotes could be effectively used when giving instructions. However, they complained that the material and instructions implemented by the lecturer in online learning were not easy to use.

After examining the previous literature, it can be concluded that online learning challenges existed before the COVID-19 pandemic started and that the challenges in the current forced environment due to COVID-19 are not different from the challenges in the normal environment. The challenges are almost the same in every context, especially in developing countries. The findings in the literature might help in answering the question of this paper, "What are the challenges of online learning faced by English language students in an EFL context during the COVID-19 pandemic?" but at the same time raise the important question, "What low-cost approach can eliminate the challenges, while maintaining a high-quality education?"

\subsection{Method and Procedures}

\subsubsection{Design}

To collect information, and to ensure that the findings of the study are in line with the participants' experiences, a quantitative approach was used.

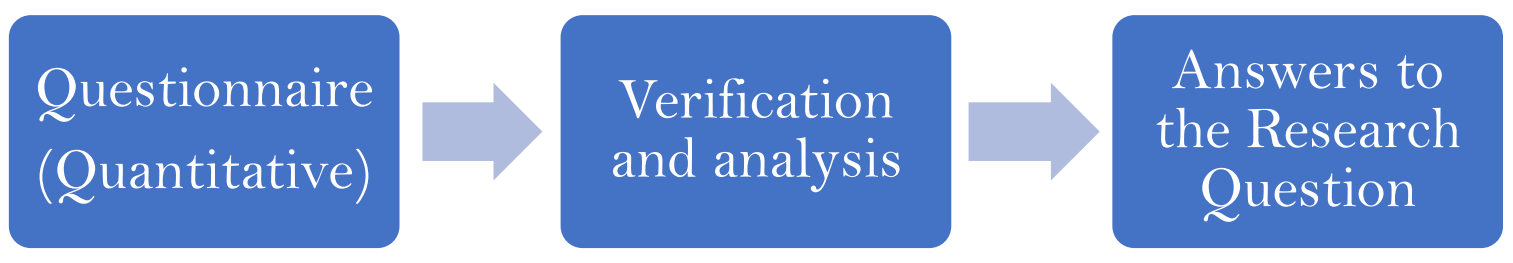

Figure-1. The process of data collection. 
Figure 1 summarizes the process of collecting data since the researchers also analyzed statistically and numerically the data collected through the questionnaire which was the instrument of the study after verifying and ensuring its reliability and validity to find the needed answers to the research question.

\subsubsection{Population and Sample}

The population of this study comprised 7,725 male and female students studying English-101 and English-99 courses at Yarmouk University in Jordan in the summer semester of the academic year 2019/2020, according to the official statistics issued by the university. The students were distributed into 28 sections (19 sections for English101 students and nine sections for English-99 students). To answer the study question, a random sample of 1,200 students was chosen. This sample provided an opportunity for all members of the study population to be represented within the sample search equally, without prejudice or direct intervention from the researchers. A simple random sampling method was chosen for two reasons:

1. The researchers were knowledgeable about the population as instructors at Yarmouk University.

2. There was homogeneity among the members of the study population as they were studying English-101 and English-99 students.

\subsubsection{Instrument of the Study}

To identify the challenges that students studying English may face when learning via the online approach, a five-point Likert-scale questionnaire was used. The answer scale for the questionnaire was translated from a verbal to a quantitative scale by giving the answer category "strongly agree" five degrees, the category "agree" four degrees, the category "moderate" three degrees, the category "disagree" two degrees, and the category "strongly disagree" one degree. These degrees were applied to all positive items, and reversed with negative items. The responses of the study sample were classified after the adoption of a relatively gradual statistical model with a view to making judgments about the means of the questionnaire and its domains as follows:

Table-1. Degree of challenge and assigned value.

\begin{tabular}{c|c}
\hline Degree & Category \\
\hline High & 3.50 and more \\
\hline Moderate & $2.50-3.49$ \\
\hline Low & Less than 2.49 \\
\hline
\end{tabular}

The questionnaire was constructed to collect data according to the following procedures. First, the related literature on the challenges that students face while learning via the online approach was reviewed since such studies contributed to a preliminary perception of how to identify the challenges to be measured by this study. Second, a number of instructors at the university who had experience in using online learning in the process of teaching and learning and experts from the computer center were consulted, their views gathered and arranged to be in line with and to reflect the experience of online learning according to the Jordanian context. Third, several items for each challenge domain were restructured.

The questionnaire prepared in its initial form consisted of 53 items distributed on the following seven challenge domains: Infrastructure (1-11), computer skills (12-16), coordination (17-24), teaching methods (25-32), motivation (33-39), assessment methods (40-47) and social aspects (48-53). The questionnaire in its final form consisted of 52 items (see Appendix A). It was translated into Arabic before distributing it to the students, so that the items were written in their native language and were clearer for them in order that more precise answers to the questionnaire could be obtained. 


\subsubsection{Questionnaire Content Validity}

Apparent validity is usually evaluated qualitatively by presenting the questionnaire to a group of experts (Roopa \& Rani, 2012). Thus, the questionnaire was presented to a group of six jury members who were experts in the field. They were asked to express their opinions about the formulation, and linguistic integrity of the items, and their appropriateness to their challenge domain. The formulation of some items was modified, in terms of construction, to eliminate ambiguity. The arbitrators proposed that Items 33, 34 and 39 relating to the motivation challenge should be deleted and replaced with other more suitable items, and also added a new item. Besides this, they also proposed that Items 48 and 53 relating to social challenges should be deleted, to make the final version of the questionnaire consist of 52 items.

\subsubsection{Questionnaire Construct Validity}

To validate the construct of the questionnaire, the researchers chose a pilot group of 30 students studying English 101 and English 99 from outside the participants of the study. The Pearson correlation coefficient of the items with the domains and with the whole questionnaire was calculated. The values of the correlation coefficient of the items with their domains, and the items with the whole questionnaire are shown in Table 2.

Table-2. Pearson correlation coefficient of the items with their domain and the items with the whole questionnaire.

\begin{tabular}{l|c|c}
\hline Domain name & $\begin{array}{c}\text { Correlation of the items with } \\
\text { their domain }\end{array}$ & $\begin{array}{c}\text { Correlation of the items with } \\
\text { the whole questionnaire }\end{array}$ \\
\hline Infrastructure & $0.541-0.727$ & $0.307-0.644$ \\
\hline Computer skills & $0.557-0.787$ & $0.425-0.628$ \\
\hline Coordination & $0.599-0.872$ & $0.589-0.733$ \\
\hline Teaching methods & $0.444-0.696$ & $0.377-0.666$ \\
\hline Motivation \& Willingness & $0.604-0.725$ & $0.355-0.447$ \\
\hline Assessment Methods & $0.547-0.687$ & $0.417-0.616$ \\
\hline Social aspect & $0.432-0.518$ & $0.432-0.518$ \\
\hline
\end{tabular}

Note: * All the values were statistically significant at $(\alpha=0.05)$.

Intercorrelation coefficients of the questionnaire domains were calculated using the Pearson correlation coefficient and they ranged from 0.432-0.872. They also were calculated with the whole questionnaire and ranged from $0.307-0.755$. All the previous values were statistically significant at $\alpha=0.05$, which shows the questionnaire had good construct validity.

\subsubsection{Questionnaire Reliability}

To ensure the reliability of the questionnaire, it was verified two weeks later by using a test-retest strategy on 85 male and female students studying English-101 and English-99 not included in the original study sample. The Pearson correlation coefficient between the estimates was measured at both times and Cronbach's coefficient alpha was used to calculate the internal consistency coefficient of the items included in the questionnaire.

Table-3. Internal consistency coefficient according to Cronbach's alpha formula and test-retest reliability of the domains with the whole questionnaire.

\begin{tabular}{l|c|c|c}
\hline Domain & $\begin{array}{c}\text { Number of } \\
\text { items }\end{array}$ & Test-retest reliability & Cronbach's alpha \\
\hline Infrastructure & 11 & 0.93 & 0.75 \\
\hline Computer Skills & 5 & 0.91 & 0.73 \\
\hline Coordination & 8 & 0.89 & 0.89 \\
\hline Teaching methods & 8 & 0.90 & 0.81 \\
\hline Motivation and willingness & 8 & 0.92 & 0.90 \\
\hline Assessment methods & 8 & 0.89 & 0.85 \\
\hline Social aspects & 4 & 0.84 & 0.87 \\
\hline Total & 52 & 0.88 & 0.83 \\
\hline
\end{tabular}


Table 3 shows the internal consistency coefficient according to Cronbach's alpha formula and the test-retest reliability of the domains with the whole questionnaire. All values were considered appropriate for the purpose of this study.

\section{RESULTS AND DISCUSSION}

The results of the questionnaire showing the assigned challenges faced by the students are shown in Table 4 .

Table-4. Means for the questionnaire domains

\begin{tabular}{l|c|c}
\hline Domain & Mean & Degree \\
\hline Teaching methods & 3.8 & High \\
\hline Social aspect & 3.7 & High \\
\hline Infrastructure & 3.6 & High \\
\hline Computer skills & 3.5 & High \\
\hline Coordination & 3.5 & High \\
\hline Assessment methods & 3.3 & Moderate \\
\hline Motivation and willingness & 3.2 & Moderate \\
\hline
\end{tabular}

Table 4 shows that the means of the questionnaire domains ranged between 3.2 and 3.8. Challenges focused on the areas of teaching methods, social aspect, infrastructure computer skills, and coordination had high degrees of challenge, while assessment methods and motivation and willingness had a moderate challenge degree.

In general, the results may be due to the dramatic and profound change in the nature of the learning and teaching process as a result of the COVID-19 pandemic. Such sudden and rapid change leads to poor infrastructure especially as Jordan is a developing country that requires a high budget and a large amount of preparation to create robust infrastructure for online learning. Students do not always have high-speed internet and most of the instructors did not make use of the mobile devices that could connect students to internet communication resources other than Zoom lectures and e-learning platform services. Thus, the online learning infrastructure, whether it be for economic or logistic reasons, was not robust enough to support new types of engagement and to provide omnipresent access to the technology tools that help learners to design, create and explore.

Furthermore, there was a high degree of computer skill challenge because students were not prepared or trained to use such skills. Notably, many Yarmouk University students are from rural communities. In such areas, using technology tools for learning is not widely possible. Students tend more to consider books and explanations of the instructors as the key sources for learning. In addition, another high degree of challenge was the teaching method domain. This may be due to the pedagogical preparation of instructors that depends mainly on direct teaching skills based on lecturing.

In a previous research conducted by the researchers of this study (Hijazi \& AlNatour, 2019) the researchers found that teachers did not know enough about how to teach in an effective way; their knowledge about how to organize, present and adapt different topics and problems according to their learners' abilities and interests was not sufficient since student teacher preparation at the university or college level focused more on the academic than on the practical aspect of teaching. In general, the results showed that the integration between what teachers know about what they teach, about the process of teaching and how to teach was not adequate and needed to be improved. If this was the case in normal physical classrooms it is likely to be an even greater issue in online classes.

In addition, the online classes at Yarmouk University were crowded, with more than 300 students in each session. The amount of teaching material was massive and needed to be covered by a deadline. Consequently, instructors did not have the time to interact with the students, and students did not have time to interact with their peers except for very short periods of time. This negatively affected the sense of community and led students to become socially impoverished and isolated. In such an environment, students cannot build genuine personal 
relationships or produce legitimate social bonding. As a result, the social aspect domain came with a high degree of challenge.

The coordination domain also came with a high degree of challenge due to the lack of understanding between the personnel involved in the learning process, lack of communication skills and lack of appropriate management. The following are the challenges and their results in more detail:

\section{1- Infrastructure}

The questionnaire results for the infrastructure domain support the existence of this challenge as $83 \%$ of the participants agreed that they had connectivity issues and trouble with stable access to the internet (as shown by the sample's responses on item 1), and 90\% of the students agreed that the infrastructure was not ready for online education (as shown by the sample's responses on item 5). The high numbers of students in each online session also affected the teaching process, $81 \%$ of the students acknowledged that the high number of students in each virtual class affected their perception of information (as shown by the sample's responses on item 8); the number of students in each session was around 300 students. During the summer semester months, most Jordanians adopted the quarantine lifestyle.

The restriction of physical movement increased the degree of internet use among Jordanian households. Most Jordanians used the internet as an entertainment tool during the curfew. According to Datareportal - Global Digital Insights (2020) the number of internet users in Jordan increased by 79 thousand (+1.2\%) between 2019 and 2020 and the number of social-media users in Jordan increased by 394 thousand (+ 7.4\%) between April 2019 and January 2020. Connections in Jordan in January 2020 were equivalent to $81 \%$ of the total population which led to an overload in capacity for the $4 \mathrm{G}$ transmission towers. $4 \mathrm{G}$ users in the country therefore faced issues regarding connectivity and bandwidth.

Table 5 shows the percentages, means and standard deviations of the participants' answers to the infrastructure items.

Table-5. Percentages, means and standard deviations of the participants' answers to the infrastructure items. For details of the items, please refer to Appendix A.

\begin{tabular}{|c|c|c|c|c|c|c|c|c|}
\hline Item & Degree & $\begin{array}{c}\text { Strongly } \\
\text { agree \% }\end{array}$ & Agree \% & $\begin{array}{c}\text { Moderate } \\
\%\end{array}$ & $\begin{array}{c}\text { Disagree } \\
\%\end{array}$ & $\begin{array}{c}\text { Strongly } \\
\text { disagree \% }\end{array}$ & Mean & SD \\
\hline 1 & High & $33 \%$ & $50 \%$ & $7 \%$ & $7 \%$ & $3 \%$ & 4.03 & 3.62 \\
\hline 2 & High & $31 \%$ & $38 \%$ & $19 \%$ & $8 \%$ & $4 \%$ & 3.84 & 3.47 \\
\hline 3 & High & $25 \%$ & $40 \%$ & $18 \%$ & $9 \%$ & $8 \%$ & 3.65 & 3.32 \\
\hline 4 & High & $32 \%$ & $39 \%$ & $15 \%$ & $6 \%$ & $8 \%$ & 3.81 & 3.47 \\
\hline 5 & High & $41 \%$ & $49 \%$ & $2 \%$ & $6 \%$ & $2 \%$ & 4.21 & 3.78 \\
\hline 6 & High & $29 \%$ & $48 \%$ & $12 \%$ & $7 \%$ & $4 \%$ & 3.91 & 3.52 \\
\hline 7 & High & $19 \%$ & $40 \%$ & $22 \%$ & $10 \%$ & $9 \%$ & 3.50 & 3.18 \\
\hline 8 & High & $1 \%$ & $6 \%$ & $12 \%$ & $53 \%$ & $28 \%$ & 4.01 & 3.57 \\
\hline 9 & Moderate & $5 \%$ & $26 \%$ & $40 \%$ & $11 \%$ & $18 \%$ & 3.11 & 2.80 \\
\hline 10 & High & $26 \%$ & $29 \%$ & $29 \%$ & $11 \%$ & $5 \%$ & 3.60 & 3.26 \\
\hline 11 & Moderate & $8 \%$ & $17 \%$ & $24 \%$ & $40 \%$ & $11 \%$ & 2.71 & 2.42 \\
\hline
\end{tabular}

\section{2- Computer skills}

Computer skills scored a high degree of challenge in the questionnaire analysis. Students reported that they had trouble using the required computer skills. Of the respondents, $77 \%$ had problems with the use of interactive applications like Zoom and Microsoft Teams internet (as shown by the sample's responses on item 14) and $72 \%$ reported that they need training on computer skills and online usage (as shown by the sample's responses on item 16). As noticed previously (Table 5), answers to items number 10 and 11 in the infrastructure domain showed that $55 \%$ of the students agreed that the available computers and mobile phones were not compatible with online education. This outdated technology made the computer skills needed for online learning harder to acquire for some 
students. Table 6 shows the percentages, means and standard deviations of the participants' answers to the computer skills items.

Table-6. Percentages, means and standard deviations of the participants' answers to the computer skills items. For details of the items, please refer to Appendix A.

\begin{tabular}{|c|c|c|c|c|c|c|c|c|}
\hline Item & Degree & $\begin{array}{c}\text { Strongly } \\
\text { agree \% }\end{array}$ & $\begin{array}{c}\text { Agree } \\
\%\end{array}$ & $\begin{array}{c}\text { Moderate } \\
\%\end{array}$ & $\begin{array}{c}\text { Disagree } \\
\%\end{array}$ & $\begin{array}{c}\text { Strongly } \\
\text { disagree \% }\end{array}$ & Mean & SD \\
\hline 12 & High & $30 \%$ & $42 \%$ & $12 \%$ & $9 \%$ & $7 \%$ & 3.79 & 3.45 \\
\hline 13 & Moderate & $10 \%$ & $11 \%$ & $47 \%$ & $16 \%$ & $16 \%$ & 2.83 & 2.54 \\
\hline 14 & High & $8 \%$ & $3 \%$ & $12 \%$ & $46 \%$ & $31 \%$ & 3.89 & 3.53 \\
\hline 15 & Moderate & $30 \%$ & $11 \%$ & $26 \%$ & $17 \%$ & $16 \%$ & 3.22 & 3.03 \\
\hline 16 & High & $30 \%$ & $42 \%$ & $12 \%$ & $10 \%$ & $6 \%$ & 3.80 & 3.45 \\
\hline
\end{tabular}

\section{3- Coordination}

Coordination in this context is defined as the mutual understanding between all the educational personnel involved in the process. The results show that mutual understanding between the educators and students was fairly low, as $57 \%$ of the students reported that the syllabus was not clear (as shown by the sample's responses on item 18 ), while $82 \%$ of the students reported that they could not easily explain to the instructor the difficulties they encountered during the semester (as shown by the sample's responses on item 22). In addition, $81 \%$ of the students reported that the rules and regulations of the online classes were either not clear or not mentioned (as shown by the sample's responses on item 19). Specific students had trouble knowing the date of the make-up exams. All these issues might be concluded as being due to the lack of clarification between the personnel involved in the learning process. Table 7 shows the percentages, means and standard deviations of the participants' answers to the coordination items.

Table-7. Percentages, means and standard deviations of the participants' answers to the coordination items. For details of the items, please refer to Appendix A.

\begin{tabular}{|c|c|c|c|c|c|c|c|c|}
\hline Item & Degree & $\begin{array}{c}\text { Strongly } \\
\text { agree \% }\end{array}$ & $\begin{array}{c}\text { Agree } \\
\%\end{array}$ & $\begin{array}{c}\text { Moderate } \\
\%\end{array}$ & $\begin{array}{c}\text { Disagree } \\
\%\end{array}$ & $\begin{array}{c}\text { Strongly } \\
\text { disagree \% }\end{array}$ & Mean & SD \\
\hline 17 & Moderate & $20 \%$ & $25 \%$ & $33 \%$ & $12 \%$ & $10 \%$ & 3.33 & 3.03 \\
\hline 18 & Moderate & $13 \%$ & $15 \%$ & $15 \%$ & $29 \%$ & $28 \%$ & 3.44 & 3.20 \\
\hline 19 & High & $3 \%$ & $8 \%$ & $8 \%$ & $46 \%$ & $35 \%$ & 4.02 & 3.62 \\
\hline 20 & Moderate & $3 \%$ & $21 \%$ & $48 \%$ & $9 \%$ & $19 \%$ & 2.80 & 2.48 \\
\hline 21 & High & $6 \%$ & $9 \%$ & $19 \%$ & $42 \%$ & $24 \%$ & 3.69 & 1.69 \\
\hline 22 & High & $2 \%$ & $5 \%$ & $11 \%$ & $42 \%$ & $40 \%$ & 4.13 & 3.71 \\
\hline 23 & Moderate & $6 \%$ & $9 \%$ & $42 \%$ & $33 \%$ & $10 \%$ & 2.68 & 2.33 \\
\hline 24 & High & $28 \%$ & $50 \%$ & $11 \%$ & $8 \%$ & $3 \%$ & 3.92 & 3.52 \\
\hline
\end{tabular}

\section{4- Teaching methods}

Teaching methods came with the highest degree of challenge, and most students reported that they faced the same issues. Only $14 \%$ of the students reported that online learning improved their writing and speaking skills (as shown by the sample's responses on item 25), while $52 \%$ of the students reported that online learning did not enhance their critical thinking and problem-solving skill (as shown by the sample's responses on item 26), which might be true since $72 \%$ of the students believed that online learning focused mainly on listening skills (as shown by the sample's responses on item 28 ).

The student's online learning experience showed a poor execution of the educational process, where most students believed that their teaching focused on memorizing over learning the core competencies of the course. All these issues may be due to the lack of instructors' knowledge, time, or training on how to make their online classes interactive. The students were not engaged in their learning, since the main focus was on listening to lectures or watching demonstrations. Their students were only passive not active participants, their learning process was 
dictated with a one-way communication mode. Teachers did not vary their teaching methods. They did not, for example, set up a workgroup environment or design activities that stimulated discussion or a hands-on experience.

Previous research conducted by one of the researchers of this study (Hijazi, 2012) before the pandemic found that the instructors' teaching methodology was based on memorization and rote learning rather than on interaction and creativity, thus, problems in the instructor's teaching methods already existed, even before the online learning methods for teaching were required, as mentioned previously.

Table 8 shows the percentages, means and standard deviations of the participants' answers to the teaching methods items.

Table-8. Percentages, means and standard deviations of the participants' answers to the teaching methods items. For details of the items, please refer to Appendix A.

\begin{tabular}{|c|c|c|c|c|c|c|c|c|}
\hline Item & Degree & $\begin{array}{l}\text { Strongly } \\
\text { agree \% }\end{array}$ & $\begin{array}{c}\text { Agree } \\
\%\end{array}$ & $\begin{array}{c}\text { Moderate } \\
\%\end{array}$ & $\begin{array}{c}\text { Disagree } \\
\% \\
\end{array}$ & $\begin{array}{c}\text { Strongly } \\
\text { disagree \% }\end{array}$ & Mean & SD \\
\hline 25 & High & $5 \%$ & $9 \%$ & $18 \%$ & $35 \%$ & $33 \%$ & 3.82 & 3.47 \\
\hline 26 & Moderate & $20 \%$ & $32 \%$ & $28 \%$ & $12 \%$ & $8 \%$ & 3.44 & 3.12 \\
\hline 27 & High & $4 \%$ & $9 \%$ & $17 \%$ & $44 \%$ & $26 \%$ & 3.79 & 3.41 \\
\hline 28 & High & $39 \%$ & $33 \%$ & $6 \%$ & $13 \%$ & $9 \%$ & 3.80 & 3.51 \\
\hline 29 & High & $25 \%$ & $24 \%$ & $45 \%$ & $4 \%$ & $2 \%$ & 3.66 & 3.26 \\
\hline 30 & High & $2 \%$ & $3 \%$ & $8 \%$ & $51 \%$ & $36 \%$ & 4.16 & 3.72 \\
\hline 31 & High & $53 \%$ & $31 \%$ & $11 \%$ & $3 \%$ & $2 \%$ & 4.30 & 3.87 \\
\hline 32 & High & $2 \%$ & $6 \%$ & $22 \%$ & $48 \%$ & $22 \%$ & 3.82 & 3.40 \\
\hline
\end{tabular}

\section{5- Motivation and willingness}

The motivation and willingness domain came with a moderate degree of challenge, based on the questionnaire. One of the highest challenges in this category was enjoyment of online classes, as $78 \%$ of the students had negative view on the methods used in class (as shown by the sample's responses on item 36 ). In addition, $67 \%$ of the students thought they would have better education if they were in a physical classroom (as shown by the sample's responses on item 35). On the other hand, more than half the student sample stated that online learning was convenient for their time and place, and it did not interfere with their sleeping times (as shown by the sample's responses on item 33). This moderate degree of challenge may due to the students' adjustments to the new learning situation. Also, more than half of the students said that they had more opportunities to re-watch recorded lectures, repeat exercises, and take their time to master concepts (as shown by the sample's responses on item 40). Thus, it may have been better for those who needed more time to understand the material.

Table 9 shows the percentages, means and standard deviations of the participants' answers to the motivation and willingness items.

Table-9. Percentages, means and standard deviations of the participants' answers to the motivation and willingness items. For details of the items, please refer to Appendix A.

\begin{tabular}{c|c|c|c|c|c|c|c|c}
\hline Item & Degree & $\begin{array}{c}\text { Strongly } \\
\text { agree } \%\end{array}$ & $\begin{array}{c}\text { Agree } \\
\mathbf{\%}\end{array}$ & $\begin{array}{c}\text { Moderate } \\
\mathbf{\%}\end{array}$ & $\begin{array}{c}\text { Disagree } \\
\%\end{array}$ & $\begin{array}{c}\text { Strongly } \\
\text { disagree } \%\end{array}$ & $\begin{array}{c}\text { Mean } \\
\text { SD }\end{array}$ \\
\hline 33 & Low & $18 \%$ & $38 \%$ & $26 \%$ & $15 \%$ & $3 \%$ & 2.47 & 2.17 \\
\hline 34 & High & $3 \%$ & $12 \%$ & $24 \%$ & $42 \%$ & $19 \%$ & 3.62 & 3.24 \\
\hline 35 & High & $22 \%$ & $45 \%$ & $22 \%$ & $10 \%$ & $1 \%$ & 3.77 & 3.36 \\
\hline 36 & High & $2 \%$ & $10 \%$ & $10 \%$ & $50 \%$ & $28 \%$ & 3.92 & 3.52 \\
\hline 37 & Low & $2 \%$ & $7 \%$ & $24 \%$ & $47 \%$ & $20 \%$ & 2.24 & 1.90 \\
\hline 38 & High & $6 \%$ & $7 \%$ & $24 \%$ & $42 \%$ & $21 \%$ & 3.65 & 3.28 \\
\hline 39 & High & $5 \%$ & $8 \%$ & $10 \%$ & $36 \%$ & $41 \%$ & 4.00 & 3.64 \\
\hline 40 & Moderate & $9 \%$ & $44 \%$ & $18 \%$ & $26 \%$ & $3 \%$ & 2.70 & 2.38 \\
\hline
\end{tabular}




\section{6- Assessment Methods}

The student's perception of the assessment methods showed a moderate degree of challenge, while emphasizing that the assessment methods evaluated the level of knowledge only. The challenges were mostly due to the unsuitable methods used to assess students. The assessment domain may have had only a moderate degree of challenge because students, in general, preferred the multiple-choice exams - 57\% agreed that they were the best way to test their knowledge (as shown by the sample's responses on item 45). However, such exams increase the degree of guessing when answering the questions, and increase the chances of cheating.

Surprisingly, the students' grades during the semesters where students were taught via the online approach during the Coronavirus era were noticeably high in comparison with the previous semesters where students were taught by conventional methods. The question that should be asked in this respect is whether the high percentages of student success are due to the adoption of online learning for the process of teaching and learning, or due to the high chances of cheating (especially as students are doing their exams from home).

Table 10 shows the percentages, means and standard deviations of the participants' answers to the assessment methods items:

Table-10. Percentages, means and standard deviations of the participants' answers to the assessment methods items. For details of the items, please refer to Appendix A.

\begin{tabular}{|c|c|c|c|c|c|c|c|c|}
\hline Item & Degree & $\begin{array}{c}\text { Strongly } \\
\text { agree \% }\end{array}$ & $\begin{array}{c}\text { Agree } \\
\%\end{array}$ & $\begin{array}{c}\text { Moderate } \\
\%\end{array}$ & $\begin{array}{c}\text { Disagree } \\
\%\end{array}$ & $\begin{array}{c}\text { Strongly } \\
\text { disagree \% }\end{array}$ & Mean & SD \\
\hline 41 & High & $33 \%$ & $31 \%$ & $22 \%$ & $10 \%$ & $4 \%$ & 3.79 & 3.44 \\
\hline 42 & Moderate & $7 \%$ & $24 \%$ & $41 \%$ & $19 \%$ & $9 \%$ & 2.99 & 2.67 \\
\hline 43 & High & $2 \%$ & $11 \%$ & $6 \%$ & $53 \%$ & $28 \%$ & 3.94 & 3.54 \\
\hline 44 & High & $3 \%$ & $5 \%$ & $6 \%$ & $53 \%$ & $33 \%$ & 4.08 & 3.66 \\
\hline 45 & Moderate & $20 \%$ & $37 \%$ & $20 \%$ & $3 \%$ & $20 \%$ & 2.66 & 2.50 \\
\hline 46 & High & $8 \%$ & $5 \%$ & $9 \%$ & $43 \%$ & $35 \%$ & 3.92 & 3.57 \\
\hline 47 & Moderate & $16 \%$ & $30 \%$ & $36 \%$ & $10 \%$ & $8 \%$ & 2.64 & 3.14 \\
\hline 48 & Moderate & $16 \%$ & $33 \%$ & $33 \%$ & $13 \%$ & $5 \%$ & 2.58 & 3.20 \\
\hline
\end{tabular}

\section{7- Social Challenges}

Social challenges within online learning had a high degree of challenge. In this domain, more than $70 \%$ of the students answered all the domain item statements with agreement (as shown by the sample's responses on items $49,50,51,52)$, showing that online learning lacks a personalized connection with the instructor. Also, discussions during assignments and social interactions between students were limited. In addition, since the university has a key role in developing social skills for young adults, the results have shown that online learning also lacks the time needed for students to develop appropriate social skills.

Table 11 shows the percentages, means and standard deviations of the participants' answers to the social challenge's items.

Table-11. Percentages, means and standard deviations of the participants' answers to the social challenge items. For details of the items, please refer to Appendix A.

\begin{tabular}{c|c|c|c|c|c|c|c|c}
\hline Item & Degree & $\begin{array}{c}\text { Strongly } \\
\text { agree } \%\end{array}$ & $\begin{array}{c}\text { Agree } \\
\mathbf{\%}\end{array}$ & $\begin{array}{c}\text { Moderate } \\
\mathbf{\%}\end{array}$ & $\begin{array}{c}\text { Disagree } \\
\mathbf{\%}\end{array}$ & $\begin{array}{c}\text { Strongly } \\
\text { disagree } \%\end{array}$ & $\begin{array}{c}\text { Mean } \\
\text { SD }\end{array}$ \\
\hline 49 & High & $29 \%$ & $46 \%$ & $11 \%$ & $6 \%$ & $8 \%$ & 3.82 & 3.47 \\
\hline 50 & High & $32 \%$ & $42 \%$ & $10 \%$ & $7 \%$ & $9 \%$ & 3.81 & 3.48 \\
\hline 51 & High & $28 \%$ & $46 \%$ & $6 \%$ & $9 \%$ & $11 \%$ & 3.71 & 3.41 \\
\hline 52 & High & $29 \%$ & $44 \%$ & $13 \%$ & $6 \%$ & $8 \%$ & 3.80 & 3.46 \\
\hline
\end{tabular}

\section{CONCLUSION}

The analysis of the questionnaire data shows that the challenges faced by students are interdependent, which means that most challenges coexist, apart from the infrastructural challenges. The degree of importance of the 
challenges, from the highest to the lowest, is as follows: Teaching methods, social aspects, infrastructure, computer skills, coordination, assessment methods, and motivation \& willingness.

What is also worth noticing is that those challenges existed even before the COVID-19 pandemic. For a developing country like Jordan, where online education was not adopted in most educational institutes before the pandemic, the lack of management and clear plans of execution, along with the poor infrastructure, made online education a challenge for both students and lecturers.

The main issue found in this study, which led to a decrease in the quality of education, was the teaching methods used by the instructors. Making the students only passive recipients of the learning process has affected the whole educational organization, leading to worse coordination between the students and the teachers, a lower motivation level and an increase in the social challenges faced by the students.

\section{RECOMMENDATIONS}

Considering the results, the researchers recommend the following:

1- Conducting future studies after the COVID-19 pandemic that examine students' satisfaction toward using an online approach in the learning and teaching process rather than using a conventional approach.

2- Conducting future studies on the suggested solutions (raised from this study and from other studies in the related literature) to overcome the challenges of using an online learning approach in the process of learning and teaching.

3- Forming partnerships between educational institutes and mobile network operators to reduce the costs on the students and increase internet availability.

4- Introducing tutorial videos teaching students how to use the interactive applications applied in the online learning process.

5- Using social media for coordination between the involved educational personnel.

Funding: This study received no specific financial support.

Competing Interests: The authors declare that they have no competing interests.

Acknowledgement: Both authors contributed equally to the conception and design of the study.

\section{REFERENCES}

Aboagye, E., \& Yawson, J. A. (2020). Teachers' perception of the new educational curriculum in Ghana. African Educational Research Journal, 8(1), 6-12.

Aboagye, E., Yawson, J. A., \& Appiah, K. N. (2020). COVID-19 and e-learning the challenges of students in tertiary institutions in Ghana. Social Education Research, 1(1), 1-7.Available at: 10.37256/ser.122020422.

Aixia, D., \& Wang, D. (2011). Factors influencing learner attitudes toward e-learning and development of e-learning environment based on the integrated e-learning platform. International Journal of e-Education, e-Business, e-Management and e-Learning, 1(3), 264-268.Available at: 10.7763/IJEEEE.2011.V1.43.

Al-Diab, N., Hijazi, D., \& AlNatour, A. (2018). The effect of online learning on students' achievement in English: A comparative study. . The Arab Journal For Arts, 15(2), 859-874.

Ali, W. (2020). Online and remote learning in higher education institutes: A necessity in light of COVID-19 Pandemic. Higher Education Studies, 1O(3), 16-25.Available at: 10.5539/hes.v 10n3p16.

Anwar, K., \& Adnan, M. (2020). Online learning amid the COVID-19 pandemic: Students' perspectives. Journal of Pedagogical Research, 1(2), 45-51.Available at: 10.33902/JPSP.2020261309.

Aydin, C., \& Tasci, D. (2005). Measuring readiness for e-learning: Reflections from an emerging country. Educational Technology E Society, 8(4), 244-257. 
Baticulon, R. E., Alberto, N., Baron, M., Mabulay, R., Rizada, L., Sy, J., . . Reyes, J. (2020). Barriers to online learning in the time of COVID-19: A national survey of medical students in the Philippines. MedRxiv preprints - Medical Education, 119.Available at: https://doi.org/10.1101/2020.07.16.20155747.

Borotis, S., \& Poulymenakou, A. (2004). E-learning readiness components: Key issues to consider before adopting e-learning interventions. In J. Nall, $\&$ R. Robson (Eds.). Paper presented at the Proceedings of World Conference on E-Learning in Corporate, Government, Healthcare, and Higher Education, (pp. 1622-1629). Chesapeake, VA: Association for the Advancement of Computing in Education (AACE).

Datareportal - Global Digital Insights. (2020). Digital 2020: Jordan. [online] Retrieved from: https://datareportal.com/reports/digital-2020-jordan.

Doghonadze, N., Halawachy, H., Samuel, A., Adedoyin, \& Aliyew, A. (2020). The degree of readiness to total distance learning in the face of COVID-19 - teachers' view (case of Azerbaijan, Georgia, Iraq, Nigeria, UK and Ukraine). Journal of Education in Black Sea Region, 5(2), 1-41.Available at: 10.31578/jebs.v5i2.197.

Evans, C., \& Fan, J. P. (2002). Lifelong learning through the virtual university. Campus-Wide Information Systems, 19(4), $127-134$.

Girik Allo, M. D. (2020). Is the online learning good in the midst of COVID-19 Pandemic? The case of EFL learners. Jurnal Sinestesia, $10(1), 1-10$.

Hijazi, D. (2012). Difficulties Jordanian non-English major university students face while learning English as a foreign language: A student perspective. Journal of Educational College, 26(2), 29-54.

Hijazi, D., \& AlNatour, A. (2019). The level of the pedagogical content knowledge of in-service English language teachers in a context of foreign language. The Arab Journal For Arts, 16(2), 681-700.

Liguori, E., \& Winkler, C. (2020). From offline to online: Challenges and opportunities for entrepreneurship education following the COVID-19 pandemic. Entrepreneurship Education and Pedagogy, 3(4), 346-351.Available at: $10.1177 / 2515127420916738$.

Mailizar, A. A., Maulina, S., \& Bruce, S. (2020). Secondary school mathematics teachers' views on e-learning implementation barriers during the COVID-19 pandemic: The case of Indonesia. EURASIA Journal of Mathematics, Science and Technology Education, 16(7), 1-9.

Mandernach, B. J., Mason, T., Forrest, K. D., \& Hackathorn, J. (2012). Faculty views on the appropriateness of teaching undergraduate psychology courses online. Teaching of Psychology, 39(3), 203-208.Available at: $10.1177 / 0098628312450437$.

Muilenburg, L. Y., \& Berge, Z. L. (2005). Student barriers to online learning: A factor analytic study. Distance Education, 26(1), 29-48.Available at: https://doi.org/10.1080/01587910500081269.

Naidu, S. (2019). The changing narratives of open, flexible and online learning. Distance Education, 4O(2), 149-152.Available at: 10.1080/01587919.2019.1612981.

O’Donoghue, J., O’Neill, K., \& Singh, G. (2004). Implementing e-learning programmes for higher education: A review of the literature. Journal of Information Technology Education: Research, 3(1), 313-323.Available at: https://doi.org/10.28945/304.

Peytcheva-Forsyth, R., Yovkova, B., \& Aleksieva, L. (2018). Factors affecting students' attitudes towards online learning - the case of Sofia University. Paper presented at the AIP Conference Proceedings 2048, 020025.

Picciano, A., \& Seaman, J. (2009). K-12 online learning: A 2008 follow-up of the survey of U.S. school district administrators. Needham, MA: Sloan Consortium.

Roopa, S., \& Rani, M. (2012). Questionnaire designing for a survey. Journal of Indian Orthodontic Society, 46(4_suppl1), 273277.Available at: https://doi.org/10.5005/jp-journals-10021-1104.

Sadeghi, M. (2019). A shift from classroom to distance learning: Advantages and limitations. International Journal of Research in English Education, 4(1), 80-88.Available at: https://doi.org/10.29252/ijree.4.1.80.

Santana, D. O., M. M, Torres Penedo, A. S., \& Pereira, V. (2018). Distance education: Advantages and disadvantages of the point of view of education and society. Dialogia, 29, 139-152. 
Shafiei Sarvestani, M., Mohammadi, M., Afshin, J., \& Raeisy, L. (2019). Students' experiences of e-learning challenges; a phenomenological study. Interdisciplinary Journal of Virtual Learning in Medical Sciences, 1O(3), 1-10.

United Nations. (2020). Policy brief: Education during COVID-19 and beyond. Retrieved from https://www.un.org/development/desa/dspd/wp-content/uploads/sites/22/2020/08/sg_policy_brief_covid19_and_education_august_2020.pdf.

Watkins, R., Leigh, D., \& Triner, D. (2004). Assessing readiness for e-learning. Performance Improvement Quarterly, 17(6), 6679.Available at: 10.1111/j.1937-8327.2004.tboo321.x.

World Bank. (2020). Remote learning and COVID-19 : The use of educational technologies at scale across an education system as a result of massive school closings in response to the COVID-19 pandemic to enable distance education and online learning. Retrieved from https://www.worldbank.org/en/topic/edutech/brief/edtech-covid-19.

World Health Organization. (2020). Novel coronavirus (2019-nCoV): Situation report - 12. Retrieved from https://www.who.int/docs/default-source/coronaviruse/situation-reports/20200201-sitrep-12ncov.pdf?sfvrsn=273c5d35_2.

\section{Appendix A}

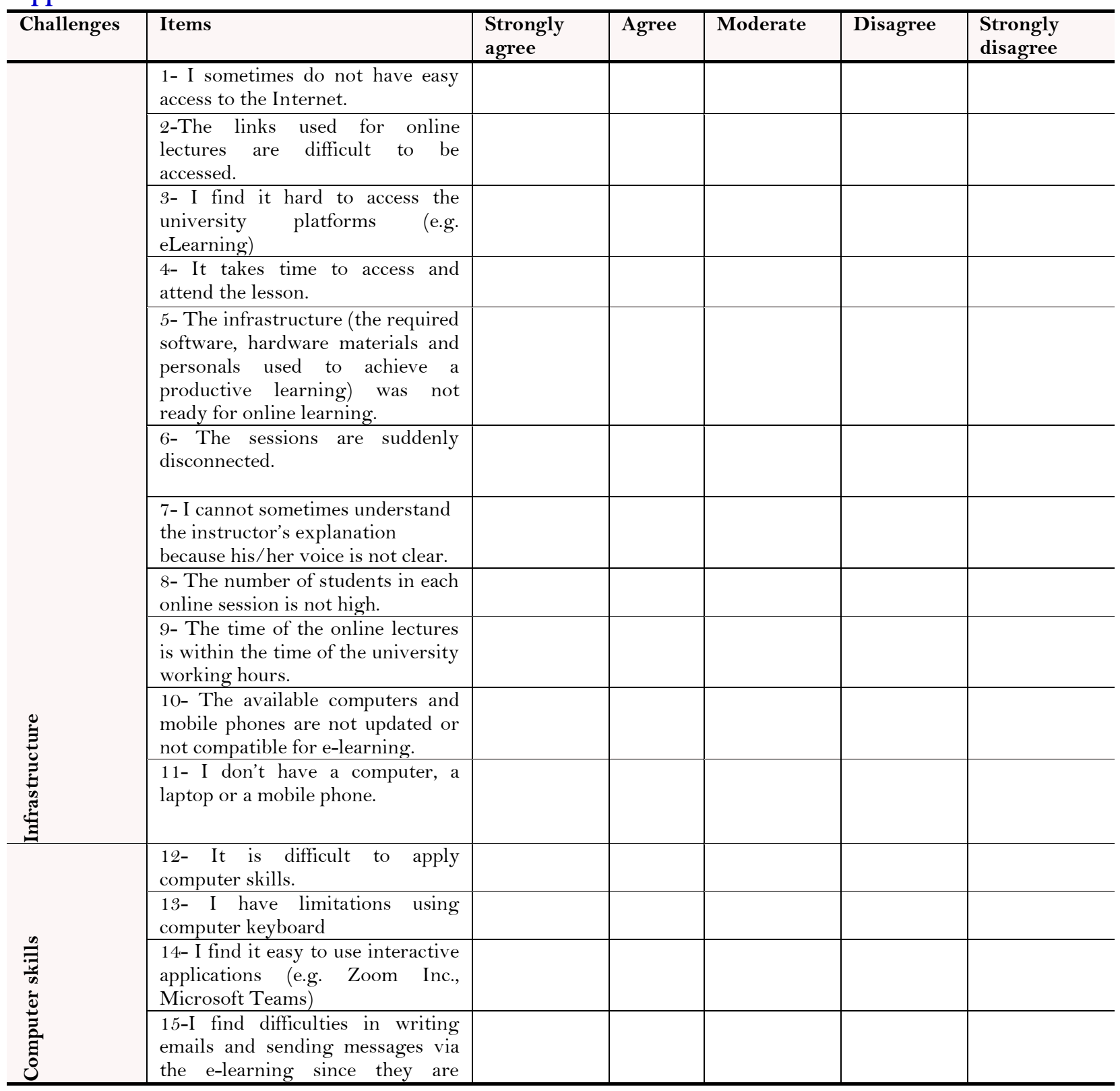




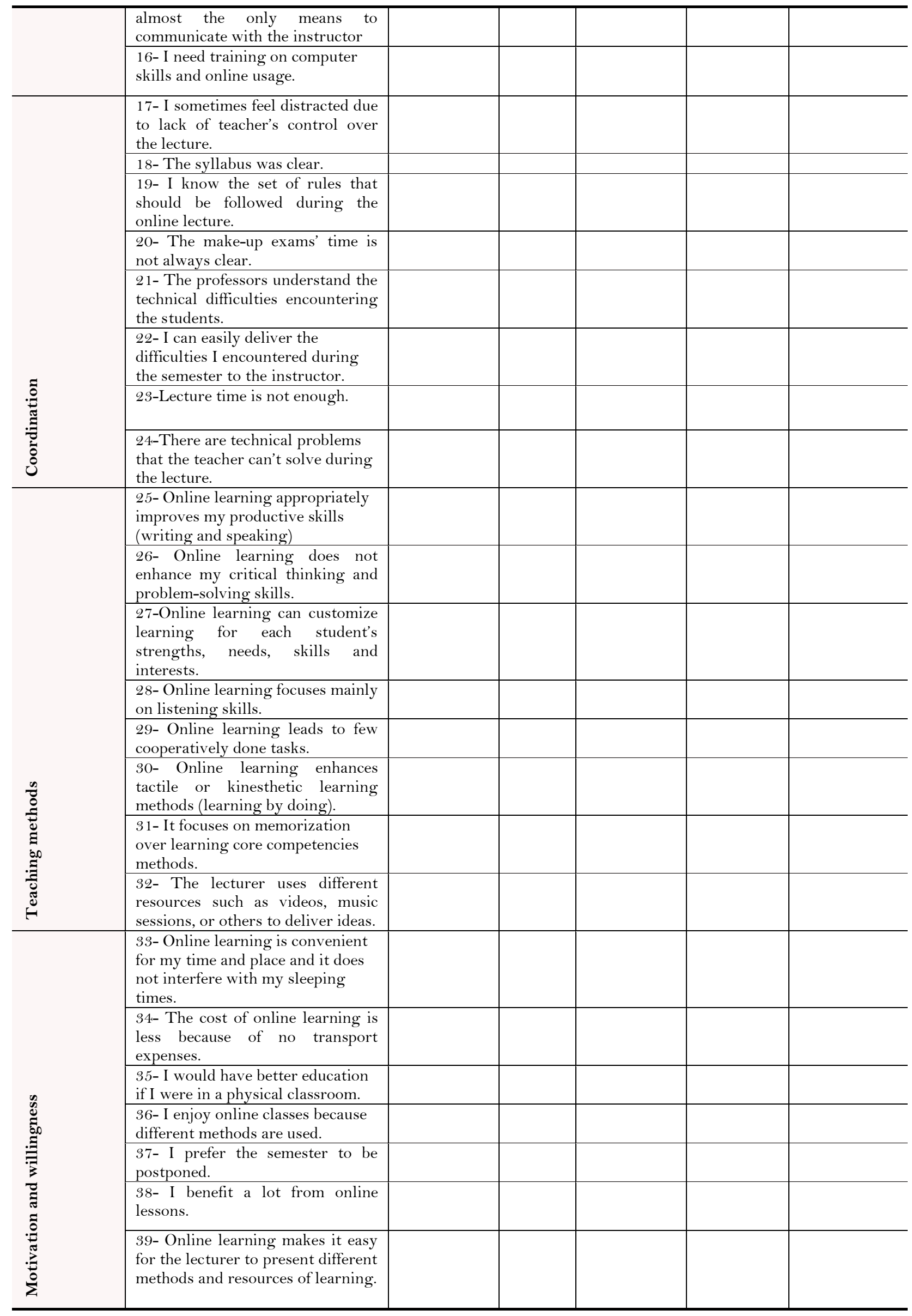




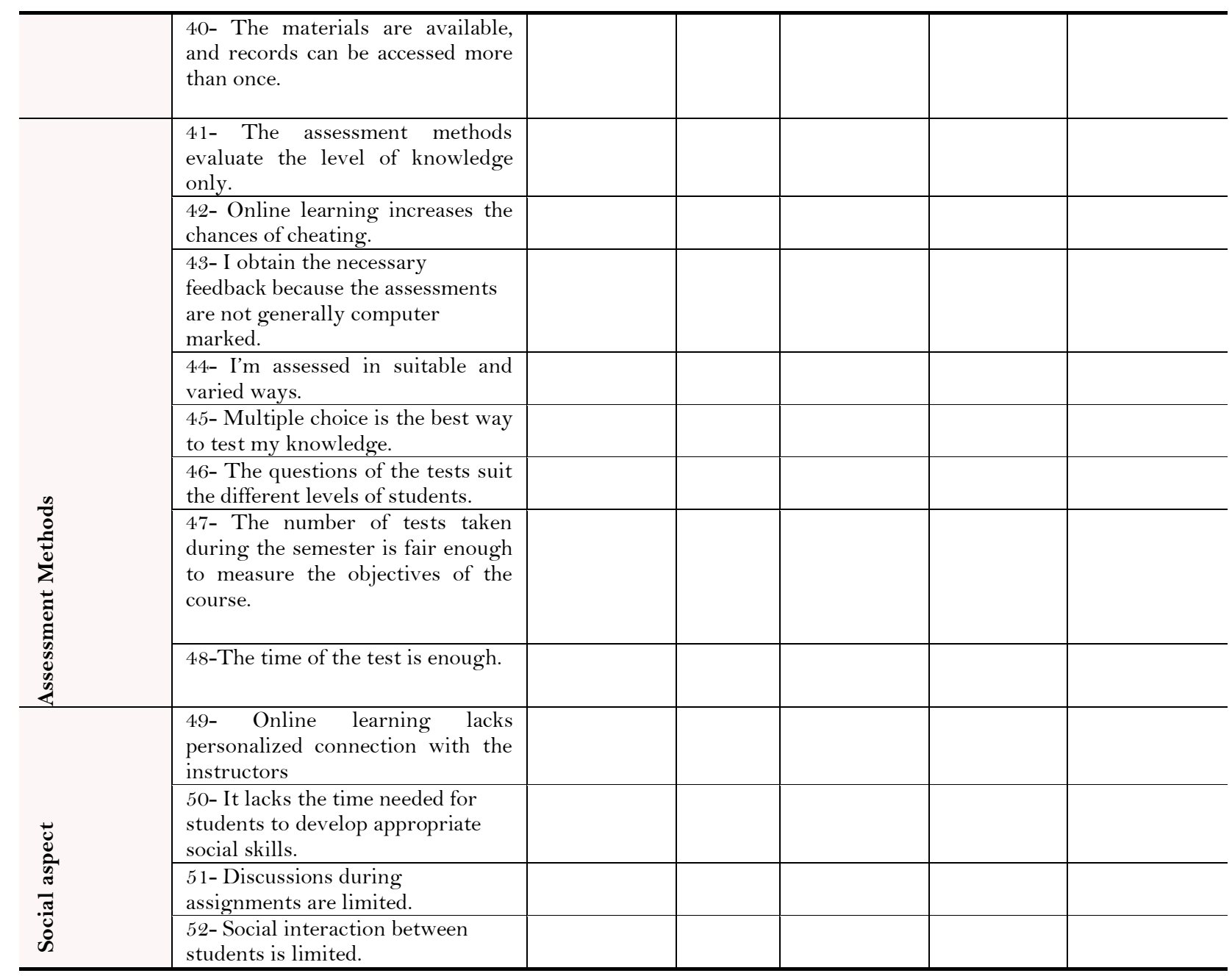

Views and opinions expressed in this article are the views and opinions of the author(s), International Journal of Education and Practice shall not be responsible or answerable for any loss, damage or liability etc. caused in relation to/arising out of the use of the content. 